\title{
Faktor-faktor yang Mempengaruhi Kinerja Pegawai
}

\author{
Suwarto \\ Widyaiswara BPSDM Prov. Jambi \\ Correspondence e_mail: suwartoireng@gmail.com
}

\begin{abstract}
The goal in this study to determine a general overview of the work ability, work dicipline and employeesperformance, in addition to knowing about the effect of work ability and work dicipline partially and simultaneously on employee performance. Research using explanatory research with a quantitative approach and data collection through a questionnaire. The sample used by 35 employees remain at the Badan Kepegawian dan Pengembangan Sumber Daya Manusia Kabupaten Muaro Jambi. Analysis of the data used is descriptive analysis method and inferential analysis by observing the classical assumption test and multiple linear analysis. The results show that the employability and dicipline affect the performance of employees is 82,3\%. While the remaining 17,7\% variable employee performance will be affected by any variables as: wages, job security, working conditions, achievements, training, work experience and others.
\end{abstract}

Keywords : Work Ability, Work dicipline, Employees Performance

\section{Pendahuluan}

Sumber daya manusia (SDM) selalu menjadi sorotan yang paling tajam dalam pelaksanaan aktivitas kerja dalam suatu organisasi maupun instansi pemerintahan yang ada, baik menyangkut kesiapan, jumlah, pendidikan, dan profesionalisme. Dimana, sumber daya manusia tersebut akan menjadi sumber yang memiliki peran penting dalam pelaksanaan pemerintahan yang baik (good governance), terutama dalam pelaksanaan otonomi daerah. Oleh karena itu, diperlukan dukungan penuh secara maksimal dan optimal dalam kesiapan aparatur dalam pelaksanaan kerja tersebut. Pegawai Negeri Sipil (PNS) mempunyai peranan yang sangat penting dalam menentukan keberhasilan penyelenggaraan pemerintahan dalam jalannya pembangunan suatu daerah melalui instansi tempat mereka bekerja. Dimana, sosok PNS disini adalah sosok individu yang memiliki kompetensi sebagai pelayan masyarakat. Selain dari tuntutan yang mengharuskan bahwa setiap PNS tersebut juga memiliki sejumlah perilaku dalam bekerja yang optimal, yaitu disiplin, ulet, kerja keras, konsekuen, konsisten, bertanggungjawab, kreatif, inovatif, pro-aktif, dan mandiri. Dalam undang-undang no 5 tahun 2014 disebutkan bahwa salah satu tugas Aparatur Sipil Negara adalah memberikan pelayanan publik yang profesional dan berkualitas. Dalam pelaksanaan tugas tersebut, para pegawai tentu memiliki kesulitan dan permasalahan yang timbul. Disinilah dituntut adanya pengetahuan dan kemampuan yang sesuai dengan bidang pekerjaan yang dilaksanakan. Sebab, apabila pekerjaan dilakukan dengan tidak berdasarkan kemampuan maupun pengetahuan, serta pengalaman yang memadai maka hasil kerja yang diinginkan tidak akan tercapai. Selain itu, pihak pimpinan sendiri harus memperhatikan kemampuan kerja dari masing-masing pegawai. Kemampuan kerja dapat disebut sebagai skill atau keahlian dalam melaksanakan pekerjaan yang diberikan. Tentunya kemampuan kerja para pegawai itu sendiri harus sesuai dengan bidang pekerjaan yang diberikan. Oleh karena itu, kemampuan kerja dapat disebut sebagai faktor eksternal yang dapat meningkatkan kinerja dari masing-masing pegawai pada Badan Kepegawaian dan Pengembangan Sumber Daya Kabupaten Muaro Jambi.

Harsey, dkk (1993:190), mengemukakan bahwa kemampuan kerja adalah pengetahuan, pengalaman, dan keahlian yang dimiliki oleh individu atau kelompok dalam pelaksanaan tugas atau aktivitas tertentu. Dengan demikian, dapat dikatakan bahwa kemampuan kerja merupakan faktor pendorong timbulnya keinginan bekerja dari seorang pegawai, dengan didukung oleh pengetahuan dan kemampuan yang mereka miliki sesuai dengan bidang kerja dan jabatan yang diemban saat ini. Dalam menunjang pelaksanaan aktivitas kerja, selain dari adanya kemampuan kerja diperlukan juga kedisiplinan dalam bekerja. Tanpa adanya kedisiplinan kerja, tentu pekerjaan yang diberikan tidak akan selesai tepat pada waktunya dan dapat menurunkan tingkat pelayanan kepada masyarakat yang berhubungan langsung dengan organisasi maupun instansi pemerintahan tersebut. Sastrohadiwiryo (2002:291), mengemukakan bahwa disiplin kerja dapat diartikan sebagai suatu sikap menghormati, menghargai, patuh dan taat terhadap peraturan uang berlaku, baik yang tertulis maupun yang tidak tertulis serta sanggup menjalankannya dan tidak mengelak untuk menerima sanksi-sanksinya apabila ia melanggar tugas dan wewenang yang diberikan kepadanya.

Dengan demikian, dengan adanya disiplin yang ditegakkan kepada setiap pegawai dalam pelaksanaan aktivitas kerja mereka sehari-hari, maka para pegawai akan terbiasa untuk mempertanggungjawabkan pekerjaan yang diberikan kepada mereka. Sementara, apabila para pegawai lalai atau sengaja tidak mentaati segala peraturan dalam instansi, mereka akan menerima hukuman maupun sanksi yang diberikan dengan sikap terbuka. Adapun tingkat kedisiplinan pegawai pertamatama dan pada umumnya dapat dilihat dari absensi 
pegawai dalam bekerja. Hal ini dikarenakan, apabila para pegawai menghargai waktu kerja dengan sebaik mungkin, maka para pegawai akan terbiasa melaksanakan pekerjaan yang diberikan sesuai dengan waktu yang telah ditentukan, tanpa harus mengulur-ulur waktu, dan tentu sangat disayangkan apabila hal tersebut tidak dapat segera diantisipasi. Kegiatan aparatur sendiri dapat dilihat seberapa besar kinerja yang mereka peroleh dalam aktivitas kerja untuk mencapai tujuan instansi yang diharapkan. Meskipun demikian, dalam suatu instansi pemerintahan, kinerja para bawahan tidak terlepas dari adanya campur tangan pemimpin dari masing-masing instansi. Hal ini disebabkan, instansi pemerintahan merupakan badan pemerintah yang mengharuskan mereka untuk memprioritaskan pelayanan kepada masyarakat umum, daripada mencari keuntungan bagi instansi mereka sendiri. Mangkunegara (2000:66), mengemukakan bahwa kinerja pegawai adalah sebagai hasil kerja secara kualitas dan kuantitas yang dicapai oleh seorang pegawai dalam melaksanakan tugasnya sesuai dengan tanggung jawab yang diberikan kepadanya. Dengan demikian, dapat dikatakan bahwa kinerja pegawai merupakan hasil kerja mereka dalam melaksanakan aktivitas ditempat kerja sehari-hari, berdasarkan bidang dan kajian pekerjaan yang sesuai dengan kemampuan mereka.

Badan Kepegawaian dan Pengembangan Sumber Daya Kabupaten Muaro Jambi. mempunyai posisi yang cukup strategis. Hal ini tercermin dari visi dan misi dinas yang kesemuanya diimplementasikan dalam dokumen yang bernama program kerja atau rencana kerja. Baik tidaknya kinerja pegawai pada khususnya dan kinerja dari Badan Kepegawaian dan Pengembangan Sumber Daya Kabupaten Muaro Jambi pada umumnya tentu dapat tercermin dari seberapa jauh target program kerja tersebut dapat direalisasikan. Penelitian berkaitan dengan elemen-elemen organisasi seperti kemampuan kerja, disiplin kerja telah banyak dilakukan oleh para peneliti. Dalam rangka pencapaian tujuan organisasi seperti yang tercantum dalam visi dan misi Badan Kepegawaian dan Pengembagan Sumberdaya Manusia Kabupaten Muaro Jambi, elemenelemen tersebut tidaklah berdiri sendiri, melainkan secara bersama-sama ikut memberikan konstribusi pada pencapaian keunggulan kompetitif yang akan membantu pada pencapaian tujuan utama organisasi berupa kinerja yang tinggi. Berdasarkan latar belakang yang telah diuraikan, penelitian yang telah dilakukan ini untuk mengetahui seberapa besar pengaruh kemampuan kerja (X1) dan disiplin kerja (X2) secara parsial dan simultan terhadap motivasi kerja (Y) pada Badan Kepegawaian dan Pengembaga Sumber Daya Manusia Kabupaten Muaro Jambi.

\section{Kemampuan Kerja}

Harsey, dkk (1993:190), mengemukakan bahwa kemampuan kerja adalah pengetahuan, pengalaman, dan keahlian yang dimiliki oleh individu atau kelompok dalam pelaksanaan tugas atau aktivitas tertentu. Dengan demikian, dapat dikatakan bahwa kemampuan kerja merupakan faktor pendorong timbulnya keinginan bekerja dari seorang pegawai, dengan didukung oleh pengetahuan dan kemampuan yang mereka miliki sesuai dengan bidang kerja dan jabatan yang diemban saat ini. Sementara, Gomez (1998:16), mengemukakan bahwa kemampuan kerja pegawai merupakan kompetensi dalam melaksanakan suatu pekerjaan, dan kemampuan kerja tersebut dapat diperbaiki melalui proses perekrutan tenaga kerja dan pemilihan individu yang terbaik untuk ditempatkan pada suatu pekerjaan tertentu. Dari dua uraian pendapat tersebut, Rubianto (2001:32), menyimpulkan bahwa kemampuan kerja sebagai suatu hasil dari integrasi empat elemen guna menghasilkan output, yaitu sarana dan prasarana modal, tenaga kerja, dan organisasi. Dimana, rasio output itu sendiri merupakan elemen-elemen terhadap produksi adalah kemampuan kerja pegawai. Robbins (2001:32), mengemukakan bahwa kemampuan kerja seseorang sangat ditentukan sekali oleh pendidikan dan pelatihan yang diperoleh, serta pengalaman terlibat dalam pekerjaannya. Menurutnya, pendidikan pada dasarnya akan menghasilkan pengetahuan, pelatihan akan menghasilkan keterampilan, sedangkan pengalaman akan menghasilkan ketangkasan dalam bekerja. Dari pendapat tersebut, dapat dikatakan bahwa dengan adanya pelatihan, pendidikan, dan pengalaman pihak instansi pegawai bekerja akan menerima sebuah laporan dari unit-unit bidang manajemen yang ada tentang perkembangan kerja dari para pegawai yang diberikan penilaian. Dimana, pendidikan dan pelatihan akan meningkatkan pengetahuan akan bidang pekerjaan yang dilaksanakan, sedangkan pengalaman akan meningkatkan wawasan para pegawai dalam menyelesaikan tugas yang diberikan.

Schuler dan Jackson (1996:33), yang mencoba menguraikan tentang beberapa indikator yang dapat dijadikan sebagai tolok ukur, maupun cerminan dari kemampuan kerja para pegawai dalam suatu organisasi, antara lain sebagai berikut ; Metode atau cara bekerja yang digunakan mencapai hasil yang maksimum, baik dari segi kuantitas dan kualitas. Pelaksanaan metode atau cara terbaik yang disiplin itu berlangsung dengan prosedur dan mekanisme yang benar, cermat, dan tepat; metode terbaik atau paling serasi; Penggunaan sarana dan prasarana, memiliki tujuan untuk memperkecil atau meniadakan hambatan kerja, sehingga hasil maksimum dapat diwujudkan; Kenggunaan metode atau cara kerja sarana dan prasarana, dapat meminimalisir resiko yang ada dan dapat merugikan dalam proses bekerja dan hasilnya, terutama memiliki jaminan yang tinggi terhadap keselamatan dan kesehatan kerja. Meskipun demikian, setidak-tidaknya resiko itu harus lebih kecil daripada jika menggunakan metode atau cara-cara alternatif lainnya; Kreativitas, Inisiatif, dan Sikap Kerja 
yang Tepat, terutama ketika menghadapi hambatanhambatan yang timbul selama bekerja. Selain itu, aspek ini menyangkut juga kesediaan dan kemampuan memperbaiki alat jika mengalami kerusakan agar tetap berfungsi. Sementara, pendapat lain juga dikemukakan oleh Ndraha (1999:43), yang mengemukakan bahwa ada beberapa indikator dalam mengukur suatu tingkat kemampuan kerja yang ada pada masing-masing pegawai, antara lain sebagai berikut : kualitas dan Kemampuan Fisik Pegawai, sarana Pendukung, dan supra sarana.

Dalam mengukur dan memberikan penilaian terhadap kemampuan kerja dari seorang pegawai dalam suatu organisasi maupun instansi yang ada, perlu diperhatikan pula beberapa faktor-faktor yang dapat mempengaruhi kemampuan kerja seseorang dalam melaksanakan aktivitas kerja yang dilakukan sehari-hari. Hal ini disebabkan, kemampuan kerja timbul bukan hanya didorong dari adanya keinginan dalam diri saja, melainkan faktor eksternal turut serta dalam menimbulkan hal tersebut. Ndraha (1999:77), mengemukakan bahwa ada beberapa faktor yang dapat mempengaruhi kemampuan kerja dari seorang pegawai dalam suatu organisasi, antara lain sebagai berikut :Pengetahuan (knowledge). Merupakan pengaplikasian wawasan dan pengetahuan yang diiringi dengan pengalaman kerja sebelumnya yang diterapkan dalam pelaksanaan tugas saat ini; Keterampilan (skills). Merupakan keahlian yang dimiliki dari individu dalam menggunakan sarana, prasarana, dan fasilitas yang diberikan terhadap kelangsungan pekerjaan yang akan dilaksanakan; Perilaku (behaviours). Merupakan sikap dan sifat dari seorang pegawai dalam menanggapi sejauhmana pekerjaan atau tugas yang diberikan tersebut, akan memberikan umpan balik terhadap dirinya maupun kelangsungan pekerjaannya.

Sementara, Gary (1999:135-137), mengemukakan bahwa pada umumnya faktor-faktor yang dapat mempengaruhi kemampuan bekerja pada diri seorang pegawai terhadap tugas yang diberikan kepada mereka, antara lain sebagai berikut :Kemampuan Intelektual, merupakan kemampuan yang diperlukan untuk menunjukkan aktivitas-aktivitas mental, dimana untuk mengetahui kemampuan intelektual seseorang, salah satu caranya adalah dengan mengetahui kemampuan pegawai dalam mengerjakan suatu tugas yang memiliki tantangan yang cukup sulit: Kemampuan Emosional, merupakan kemampuan dari individu pada umumnya, dan pada pegawai pada khususnya dalam mengetahui apa yang kita dan orang lain rasakan, termasuk cara yang tepat untuk menangani masalah yang timbul dalam melaksanakan pekerjaan yang diberikan tersebut: Kemampuan Fisik, merupakan salah satu fakor pendukung yang harus dimiliki oleh setiap orang dalam melakukan pekerjaannya. Hal ini dikarenakan, kemampuan fisik diperlukan dalam hal melaksanakan tugas-tugas yang menuntut stamina, koordinasi tubuh atau keseimbangan, kekuatan, kecepatan, dan kelenturan atau fleksibilitas tubuh. Dengan mengetahui kemampuan fisik para pegawainya, pimpinan akan lebih mengetahui pegawai mana yang sesuai untuk melaksanakan pekerjaan yang menuntut kemampuan fisik paling banyak. Dengan demikian, dapat dikatakan bahwa ujung tombak dalam mengupayakan usaha peningkatan kemampuan seseorang adalah bersumber dari diri orang tersebut. Kemampuan diri seorang pegawai sebagai suatu konsep menunjukkan adanya kaitan antara output dengan waktu yang dibutuhkan untuk melaksanakan tugas seorang pegawai, yang berarti seorang pegawai hendaklah menunjukkan kemampuan kualitas kerja yang sesuai dengan standard yang telah ditentukan.

\section{Disiplin Kerja}

Fathoni (2006:130), mengemukakan bahwa dalam dunia kerja, disiplin kerja pada para pegawai dapat diartikan sebagai sikap pegawai yang mematuhi semua peraturan dan ketentuan yang berlaku dalam suatu organisasi, seperti datang dan pulang tepat waktu, mengerjakan semua pekerjaan dengan baik, maupun tidak mangkir dari tugas yang diberikan. Hasibuan (2002:193), menyatakan bahwa disiplin kerja adalah kesadaran dan kesediaan seseorang mentaati semua peraturan dan norma-norma sosial yang berlaku. Kesadaran adalah sikap seseorang yang secara sukarela mentaati semua peraturan dan sadar akan tugas dan tanggung jawabnya, kesediaan adalah suatu sikap, tingkah laku, dan peraturan perusahaan, baik yang tertulis maupun tidak. Sementara, hubungan antara pegawai dan organisasi merupakan sesuatu yang dinamis; hubungan itu harus berubah sebab setiap pihak harus menyesuaikan terhadap perkembangan yang terjadi, baik harapan terhadap yang lain dan sumbangan yang akan diberikannya sebagai imbalan tersebut. Pada tingkat formal, kedua proses tersebut telah ditetapkan untuk dipakai oleh organisasi dan pegawai, apabila salah satu merasa bahwa harapan terhadap yang lain telah dilanggar. Sastrohadiwiryo (2002:291), mengemukakan bahwa disiplin kerja dapat diartikan sebagai suatu sikap menghormati, menghargai, patuh dan taat terhadap peraturan uang berlaku, baik yang tertulis maupun yang tidak tertulis serta sanggup menjalankannya dan tidak mengelak untuk menerima sanksi-sanksinya apabila ia melanggar tugas dan wewenang yang diberikan kepadanya. Dengan demikian, dapat disimpulkan bahwa disiplin kerja adalah bentuk pengendalian diri pegawai dan pelaksanaan yang teratur, serta menunjukkan tingkat kesungguhan tim kerja dalam suatu organisasi. Selain itu, kecakapan disiplin ditunjukkan dengan tidak mempertimbangkan apakah aturan yang ditaati bermanfaat atau tidak. Hal ini pada akhirnya membuat suatu penekanan terhadap disiplin kerja yang dapat membuat pegawai mampu bergairah untuk bekerja, atau malah sebaliknya. 
Hasibuan (2002:195), mengemukakan bahwa ada beberapa indikator yang dapat dijadikan sebagai tolok ukur dalam melihat sejauhmana tingkat kedisiplinan seorang pegawai dalam suatu organisasi, antara lain sebagai berikut : Tujuan dan Kemampuan. Tujuan dan kemampuan ikut mempengaruhi tingkat kedisiplinan karyawan. Tujuan yang akan dicapai harus jelas dan ditetapkan secara ideal serta cukup menantang bagi kemampuan karyawan. Hal ini berarti bahwa tujuan (pekerjaan) yang dibebankan kepada karyawan harus sesuai dengan kemampuan karyawaan bersangkutan, agar dia bekerja sungguh-sungguh dan disiplin dalam mengerjakannya: Kepemimpinan. Kepemimpinan sangat berperan dalam menentukan kedisiplinan karyawan. Karena pimpinan dijadikan teladan dan panutan oleh para bawahannya. Pimpinan jangan mengharapkan kedisiplinan bawahannya baik jika dia sendiri kurang disiplin: Balas Jasa. Balas jasa (gaji dan kesejahteraan) ikut mempengaruhi kedisiplinan karyawan karena balas jasa akan memberikan kepuasan dan kecintaan karyawan terhadap perusahaan / pekerjaannya. Jika kecintaan karyawan semakin baik terhadap pekerjaan, kedisiplinan mereka akan semakin baik pula: Keadilan. Keadilan ikut mendorong terwujudnya kedisiplinan karyawan, karena ego dan sifat manusia yang selalu merasa dirinya penting dan minta diperlakukan sama dengan manusia lainnya. Dengan keadilan yang baik akan menciptakan kedisiplinan yang baik pula. Jadi, keadilan harus diterapkan dengan baik pada setiap perusahaan supaya kedisiplinan karyawan perusahaan baik pula: Waskat. Waskat (pengawasan melekat) adalah tindakan nyata dan paling efektif dalam mewujudkan kedisiplinan karyawan perusahaan. Waskat efektif merangsang kedisiplinan dan moral kerja karyawan. Karyawan merasa mendapat perhatian, bimbingan, petunjuk, pengarahan, dan pengawasan dari atasannya: Ketegasan. Ketegasan pimpinan dalam melakukan tindakan akan mempengaruhi kedisiplinan karyawan perusahaan. Pimpinan harus berani dan tegas, bertindak untuk menghukum setiap karyawan yang indisipliner sesuai dengan sanksi hukuman yang telah ditetapkan. Ketegasan pimpinan menegur dan menghukum setiap karyawan yang indisipliner akan mewujudkan kedisiplinan yang baik pada perusahaan tersebut: Sanksi. Sanksi berperan penting dalam memelihara kedisiplinan karyawan. Dengan sanksi hukuman yang semakin berat, karyawan akan semakin takut melanggar peraturanperaturan perusahaan, sikap, perilaku indisipliner karyawan akan berkurang. Sementara, Sulistiyani dan Rosidah (2003:236), mengemukakan bahwa dalam memberikan penilaian terhadap disiplin kerja para pegawai, hendaknya mengikuti beberapa prinsip-prinsip atau dasar-dasar, antara lain sebagai berikut :

Keadilan dan layanan sama rata; Pertimbangan minat dan keperluan kerja; Kebebasan tunduk pada peraturan; Menghormati sesama individu; Hubungan sesama manusia untuk suasana kerja yang harmonis;
Harmonisasi pegawai dan pimpinan.Dengan adanya disiplin kerja dalam diri seseorang, maka akan menjadikan individu tersebut sebagai manusia yang dapat memimpin diri mereka sendiri dalam hidupnya saat ini maupun di masa yang akan datang. Hal ini dikarenakan, disiplin kerja bagi setiap individu maupun pegawai pada khususnya adalah mutlak dalam usaha mewujudkan satu masyarakat yang memiliki kepatuhan maupun ketaatan terhadap peraturan dan norma-norma yang ada dalam lingkungan kerja pada organisasi tersebut. Selain itu, dengan adanya disiplin kerja, akan melahirkan individu-individu yang kreatif, serta mempunyai kesadaran harga diri dalam masyarakat yang bergerak ke arah kemajuan. Selanjutnya, faktor-faktor yang dapat mempengaruhi disiplin kerja sendiri menurut Sastrohadiwiryo (2002:301) dapat dibedakan menjadi beberapa hal, antara lain sebagai berikut ; Adanya peraturan atau tata tertib perusahaan; Adanya tindakan korektif atau hukuman bagi pelanggaran tata tertib; Adanya rasa tanggung jawab seseorang terhadap tugastugas yang diberikan kepadanya; Harus adanya tujuan dan kemampuan, tujuan ini harus dinyatakan dengan jelas dan ditetapkan secara ideal dan cukup menantang bagi kemampuan karyawan. Pekerjaan yang dibebankan harus disesuaikan dengan kemampuan karyawan yang bersangkutan; Harus adanya teladan pimpinan, sangat berperan dalam menetukan kedisiplinan karyawan, karena pemimpin dijadikan teladan dan panutan oleh bawahannya; Harus adanya balas jasa, hal ini ikut mempengaruhi kedisiplinan karyawan, karena balas jasa akan memberikan kepuasan dan kecintaan karyawan terhadap pekerjaannya; Harus adil, karena dengan keadilan akan mendorong terwujudnya kedisiplinan karyawan hal ini disebabkan ego dan sifat manusia yang selalu merasa dirinya penting dan minta diperlakukan sama dengan manusia lainnya; Waskat (pengawasan melekat), yaitu suatu tindakan nyata dan efektif untuk mencegah atau mengetahui kesalahan, membetulkan kesalahan, memelihara kedisiplinan, menjadi sistemsistem kerja yang paling efektif dan menciptakan sistem internal kontrol yang terbaik dalam pencapaian tujuan perusahaan; Ketegasan, dalam menegur dan menghukum setiap karyawan yang indisipliner akan mewujudkan kedisiplinan yang baik pada perusahaan tersebut; dan hubungan terhadap manusia, yaitu hubungan yang harmonis ikut mencipakan kedisiplinan yang baik pada suatu perusahaan.

\section{Kinerja Pegawai}

Mangkunegara (2000:66), mengemukakan bahwa kinerja pegawai adalah sebagai hasil kerja secara kualitas dan kuantitas yang dicapai oleh seorang pegawai dalam melaksanakan tugasnya sesuai dengan tanggung jawab yang diberikan kepadanya. Konsep kinerja lainnya juga dikemukakan Robbins (2001:74), kinerja pegawai merupakan ukuran dari hasil yang menggambarkan sejauhmana aktivitas seseorang dalam melaksanakan 
tugas dan berusaha mencapai tujuan dalam melaksanakan tugas dan berusaha mencapai tujuan yang telah ditetapkan. Sementara, Schermerhorn (2005:97), mengemukakan bahwa kinerja pegawai adalah kuantitas dan kualitas dari pencapaian tugas oleh seorang individu atau kelompok pada pekerjaan. Selanjutnya maanfaat kinerja Handoko (2002:135), mengemukakan secara lebih rinci dalam memberikan penjelasan tentang manfaat yang dapat diperoleh dengan adanya penilaian kinerja pegawai, antara lain sebagai berikut :Perbaikan Kinerja. Umpan balik pelaksanaan kerja memungkinkan pegawai, pimpinan, dan unit pengolahan tenaga kerja dapat memperbaiki kegiatan-kegiatan mereka untuk memperbaiki kinerja; Penyesuaian Kompensasi. Atas dasar penilaian kinerja dapat membantu pengambilan keputusan dalam menentukan kenaikan upah / kompensasi, pemberian bonus, dan bentuk kompensasi / imbalan lainnya; Keputusan Penempatan. Promosi, transfer, dan demosi biasanya didasarkan pada kinerja atau antisipasinya; Kebutuhan Latihan dan Pengembangan. Kinerja yang jelek mungkin menunjukkan kebutuhan latihan, demikian juga kinerja yang baik mungkin mencerminkan potensi yang harus dikembangkan; Perencanaan dan Pengembangan Karir. Umpan balik kinerja mengarahkan keputusan-keputusan karir, yaitu tentang jalur karir tertentu yang harus diteliti; Penyimpanan Proses Staffing. Kinerja yang baik atau jelek bisa mencerminkan kekuatan / kelemahan proses staffing yang dilaksanakan; Ketidakakuratan Informasi. Kinerja yang jelek mungkin menunjukkan kesalahankesalahan dalam informasi anlisis jabatan, rencanarencana sumber daya manusia, atau komponenkomponen lain dalam sistem informasi sumber daya manusia; Kesalahan Desain Pekerjaan. Kinerja yang jelek mungkin merupakan suatu tanda kesalahan dalam desain pekerjaan. Penilaian kerja dapat membantu diagnose kesalahan tersebut; Kesempatan Kerja Yang Adil. Penilaian kinerja secara akurat dapat memberikan sumbangan pada pengambilan keputusan internal tanpa diskriminasi; Tantangan Eksternal.Kadang-kadang kinerja dipengaruhi juga faktor-faktor diluar lingkungan kerja seperti keluarga, kesehatan, kondisi finansial, atau masalah-masalah pribadi lainnya. Dengan diketahuinya masalah-masalah tersebut, unit yang mengelola sumber daya manusia mungkin dapat memberikan bantuan penyelesaiannya.

Pangabean (2002:142), tahap identifikasi merupakan tahap awal dari proses yang terdiri dari atas penentuan unsur-unsur yang akan diamati. Dimana, kegiatan ini diawali dengan melakukan analisis pekerjaan agar dapat mengenali unsur-unsur yang akan dinilai dan dapat mengembangkan skala penilaian. Sementara, Siagian (1999:141), menjelaskan bahwa beberapa hal tentang bagaimana suatu penilaian kinerja yang baik sangat bermanfaat untuk berbagai kepentingan, antara lain sebagai berikut :
1. Mendorong peningkatan kinerja. Dengan mengetahui hasil kinerja, ketiga pihak yang terlibat dapat mengambil berbagai langkah yang diperlukan agar kinerja para pegawai lebih meningkat lagi di masamasa yang akan datang.

2. Sebagai bahan pengambilan keputusan dalam pemberian imbalan. Telah dimaklumi bahwa imbalan yang diberikan oleh organisasi kepada para anggotanya tidak hanya terbatas pada upah dan/atau kompensasi yang merupakan penghasilan tetap bagi para anggota yang bersangkutan, akan tetapi juga berbagai imbalan lainnya, seperti bonus pada akhir tahun, hadiah pada hari-hari besar tertentu, dan bahkan juga oleh banyak organisasi niaga pemilikan sejumlah saham sekolah. Keputusan tentang siapa yang berhak menerima berbagai imbalan tersebut dapat didasarkan antara lain pada hasil penilaina atas kinerja pegawai yang bersangkutan.

3. Untuk kepentingan mutasi pegawai. Kinerja seseorang di masa lalu merupakan dasar bagi pengambilan keputusan mutasi baginya di masa depan, apapun bentuk mutasi tersebut, seperti promosi, alih tugas, alih wilayah maupun demosi.

4. Guna menyusun program pendidikan dan pelatihan, baik yang dimaksudkan untuk mengatasi berbagai kekurangan dan kelemahan, maupun untuk mengembangkan potensi pegawai yang ternyata belum sepenuhnya digali dan yang terungkap melalui penilaian kinerja .

5. Membantu para pegawai menentukan rencana karirnya dan dengan bantuan bagian kepegawaian menyusun program pengembangan karier yang paling tepat, dalam arti sesuai dengan kebutuhan para pegawai dan dengan kepentingan organisasi.

Untuk dapat mengevaluasi kinerja pegawai secara objektif dan akurat, maka perlu ada tolok ukur tingkat kinerja. Pengukuran tersebut berarti memberi kesempatan bagi para pegawai untuk mengetahui tingkat kinerja mereka. Selain itu, dengan tolok ukur tersebut, maka penilaian yang dilakukan kepada masing-masing pegawai akan terlaksana sesuai dengan pencapaian yang diinginkan, tanpa harus merugikan pihak-pihak tertentu. Aroef (2006:102), mengemukakan bahwa indikatorindikator yang dapat digunakan sebagai tolok ukur dari kinerja individu seorang tenaga kerja (pegawai), yakni : Hasil kerja (Merupakan sebuah hasil dari adanya pelaksanaan aktivitas kerja dari seorang pegawai dalam suatu organisasi yang berlandaskan tujuan yang ingin diraih. Dimana, hasil kerja tersebut akan menjadi sebuah penilaian berdasarkan atas ketepatan waktu dan ketelitian kerja dari pegawai tersebut dalam bekerja); Kompetensi (Merupakan keahlian atau kemampuan yang dimiliki oleh seorang pegawai dalam suatu organisasi yang memudahkan pegawai tersebut dalam melaksanakan pekerjaan yang diberikan kepada mereka, sesuai dengan bidang dan kajian ilmu dari masingmasing pegawai tersebut); Perilaku kerja (Merupakan 
sikap dalam menghadapi situasi dan kondisi yang terjadi dalam suatu organisasi, dimana pegawai akan dituntut untuk berbuat yang terbaik bagi organisasi tempat mereka bekerja): Potensi kemampuan (Merupakan tingkat kemampuan yang dimiliki oleh seorang pegawai ketika dihadapkan dengan sejumlah pekerjaan. Dimana, kemampuan tersebut akan menunjukkan sejauhmana pegawai mampu untuk melaksanakan tugas yang diberikan kepada mereka, atau malah sebaliknya): Teknologi (Merupakan sarana maupun prasarana, serta fasilitas yang mendukung dan memudahkan para pegawai untuk melaksanakan maupun menyelesaikan tanggung jawab yang diberikan kepada mereka).

Sedarmayanti (2002:102), mengemukakan bahwa ada beberapa tolok ukur dalam melakukan penilaian terhadap kinerja pegawai pada aktivitas kerja mereka, antara lain sebagai berikut : 1) Kualitas kerja (quality of work). menurut Wilson dan Heyel (1987:101) mengatakan bahwa "Quality of work (kualitas kerja) menunjukkan sejauh mana mutu seorang pegawai dalam melaksanakan tugas-tugasnya meliputi ketepatan, kelengkapan, dan kerapian". Kualitas kerja dapat diukur melalui ketepatan, kelengkapan, dan kerapian. Yang dimaksud ketepatan adalah ketepatan dalam melaksanakan tugas dan pekerjaan, artinya terdapat kesesuaian antara rencana kegiatan dengan sesaran atau tujuan yang telah ditetapkan. Yang dimaksud dengan kelengkapan adalah kelengkapan ketelitian dalam melaksanakan tugasnya. Yang dimaksud kerapian adalah kerapian dalam melaksanakan tugas dan pekerjaannya; 2) Ketepatan waktu (promptness). Karakteristik pengukuran yang dilaporkan secara real time atau segera setelah peristiwa itu langkah-langkah yang harus diambil dalam suatu pekerjaan. Sebuah pengukuran yang tepat waktu dapat digunakan untuk tindakan preventif atau korektif oleh pengambilan kebijakan, sebagai lawan dari pengukuran yang mungkin tidak akurat tetapi hanya berfungsi sebagai laporan status karena jeda waktu antara peristiwa dan laporan. Dengan adanya rencana dan waktu yang tepat apapun dapat kita atur. Maksudnya bahwa suatu rencana yang sudah kita buat dan ditentukan waktunya lalu kita beraktivitas sesuai dengan semua itu hasil yang dicapai akan memuaskan. Hasil dari semua itu akan memaksimalkan efisiensi aktivitas yang sudah kita rencanakan: 3) Inisiatif (initiative). Inisiatif adalah dorongan untuk mengidentifikasi masalah atau peluang dan mampu diambil tindakan nyata untuk menyelesaikan masalah atau menangkap Peluang, tahap berikutnya seorang pegawai negeri sipil tidak hanya mengidentifikasi masalah namun mampu mengambil tindakan nyata agar masalah itu bisa selesai dan juga mampu mengambil tindakan nyata dalam mengangkap peluang dan mewujudkanya menjadi kenyataan; 4) Kesanggupan kerja (capability). Menurut pendapat (Robbins,1998) kesanggupan kerja adalah"suatu kapasitas individu untuk mengerjakan berbagai tugas dalam suatu pekerjaan". Salah satu faktor yang sangat penting dan berpengaruh terhadap keberhasilan karyawan di dalam melaksanakan suatu pekerjaan adalah kemampuan kerja. Kemampuan merupakan potensi yang ada dalam diri seseorang untuk berbuat sehingga memungkinkan seseorang untuk dapat melakukan pekerjaan ataupun tidak dapat melakukan pekerjaan tersebut; 5) Keterampilan berkomunikasi (communication). Menurut Eggen (2004) bahwa keterampilan komunikasi adalah "ketika guru menggunakan pengetahuannya dalam teknik komunikasi verbal, nonverbal dan melalui media komunikasi secara efektif untuk mempertahankan keaktifan dalam bertanya, kolaborasi dan interaksi siswa yang sifatnya mendukung di dalam kelas".

Mangkunegara (2005:13-14) merumuskan faktor-faktor yang mempengaruhi pencapaian kinerja seorang karyawan, antara lain sebagai berikut :
Human Performance
$=$ Ability $x$ Motivation
Motivation
$=$ Attitude $x$ Situation
Ability
$=$ Knowledge $x$ Skill

Faktor Kemampuan (Ability).Secara psikologis, kemampuan (ability) terdiri dari kemampuan potensi (IQ) dan kemampuan reality (knowledge + skill). Artinya, pimpinan dan karyawan yang memiliki IQ di atas rata-rata (IQ 110 - 120) apalagi IQ superior, very superior, gifted dan genius dengan pendidikan yang memadai untuk jabatannya dan terampil dalam mengerjakan pekerjaan sehari-hari, maka akan lebih mudah mencapai kinerja maksimal. Faktor Motivasi (Motivation). Motivasi diartikan suatu sikap (attitude) pimpinan dan karyawan terhadap situasi kerja (situation) di lingkungan organisasinya. Mereka yang bersikap positif (pro) terhadap situasi kerjanya akan menunjukkan motivasi kerja tinggi dan sebaliknya jika mereka bersikap negatif (kontra) terhadap situasi kerjanya akan menunjukkan motivasi kerja yang rendah. Situasi kerja yang dimaksud mencakup antara lain hubungan kerja, fasilitas kerja, iklim kerja, kebijakan pimpinan, pola kepemimpinan kerja dan kondisi kerja. Siagian (2007:29) adapun faktor-faktor yang mempengaruhi pencapaian kinerja pegawai dapat disimpulkan menjadi dua golongan, yaitu :1) Faktor yang ada pada diri individu, yaitu umur, temperamen, keadaan fisik individu, dan motivasi; 2) Faktor yang ada di luar individu, yaitu kondisi fisik seperti, suara, penerangan, waktu, istirahat, lama kerja, upah, bentuk organisasi, lingkungan sosial dan keluarga.

Beberapa penelitian terdahulu dengan menggunakan variabel kemampuan kerja, disiplin kerja, dan kinerja pegawai telah dilakukan oleh beberapa peneliti, antara lain sebagai berikut: Anggraeni, N (2012), hasil penelitiannya menunjukkan bahwa kemampuan dan motivasi secara bersama-sama mempunyai pengaruh positif dan signifikan terhadap kinerja pegawai Sekolah Tinggi Seni Indonesia (STSI) Bandung. M. Oktaviannur dan Adhetya Pratama (2016), hasil penelitian menunjukkan bahwa motivasi kerja 
berpengaruh positif terhadap kinerja karyawan dan disiplin kerja berpengaruh positif terhadap kinerja karyawan. Bangun dan Kasmir (2019), hasil penelitiannya menunjukkan bahwa disiplin memiliki pengaruh positif dan signifikan terhadap kinerja. Sedangkan hasil penelitian Sarwani (2016) menunjukkan bahwa secara simultan atau parsial, disiplin kerja dan lingkungan kerja memiliki pengaruh yang signifikan terhadap kinerja karyawan. Jeffrey dkk, yang meneliti variabel Disiplin Kerja dan pengaruhnya terhadap kinerja menyimpulkan bahwa disiplin kerja memiliki pengaruh positif dan signifikan terhadap Kinerja Karyawan. Nurul Laras dkk, mengungkapkan hasil penelitianya bahwa disiplin kerja berpengaruh signifikan terhadap kinerja karyawan Koperasi Al Hudori Palembang.

\section{Hipotesis}

Hipotesis penelitian merupakan dugaan sementara dari apa yang diteliti. Dari uraian diatas maka hipotesis pada penelitian ini adalah :

1. Kemampuan kerja (X1), disiplin kerja (X2), dan Kinerja (Y) pada pada Badan kepegawaian dan Pengembangan Sumber Daya Manusia Kabupaten Muaro Jambi berada pada kategori baik.

2. Kemampuan kerja (X1) berpengaruh signifikan terhadap Kinerja (Y) pada pada Badan kepegawaian dan Pengembangan Sumber Daya Manusia Kabupaten Muaro Jambi

3. Disiplin kerja (X2) berpengaruh signifikan terhadap Kinerja (Y) pada pada Badan kepegawaian dan Pengembangan Sumber Daya Manusia Kabupaten Muaro Jambi

4. Kemampuan kerja (X1) dan disiplin kerja (X2) secara bersama-sama berpengaruh signifikan terhadap Kinerja (Y) pada Badan kepegawaian dan Pengembangan Sumber Daya Manusia Kabupaten Muaro Jambi

\section{Metode}

Berdasarkan rumusan masalah dan tujuan penelitian, jenis penelitian yang digunakan adalah explanatory research (penjelasan). Faisal (2008:21) menjelaskan tentang explanatory research untuk menguji hubungan antara variabel yang dihipotesiskan. Populasi dalam penelitian ini adalah 39 pegawai Badan Kepegawaian dan Pengembangan Sumber Daya Manusia Kabupaten Muaro Jambi. Sampel yang digunakan dalam penelitian ini sebesar 35 pegawai. Teknik pengambilan sampel menggunakan teknik Proporsional Random Sampling. Kuesioner untuk masing-masing variabel terdiri dari 10 butir pertanyaan. Sedangkan untuk mengumpulkan dan menganalisis bukti empiris (data) dilakukan pendekatan kuantitatif dengan melakukan pengujian data secara statistik, serta dilakukan secara sistematis agar dapat memahami fenomena sosial yang sedang diteliti (Sugiyono,
2005:52). Pendekatan kuantitatif digunakan secara khusus untuk dapat menganalisa kemampuan kerja dan disiplin kerja terhadap Kinerja pegawai. Alat analisis yang digunakan adalah analisis regresi linear.

\section{Hasil \\ Analisis Deskriptif \\ Variabel Kemampuan Kerja}

Hasil skor rata-rata jawaban responden mengenai kemampuan kerja (X1) sebesar 3.240 dengan rentang skala $3.150-3.750$, hal ini menunjukkan dengan adanya metode atau cara kerja yang digunakan, metode terbaik atau paling serasi, penggunaan sarana dan prasarana, penggunaan metode atau cara kerja sarana dan prasarana, serta kreativitas, inisiatif, dan sikap kerja yang tepat, maka dapat meningkatkan kinerja pegawai pada Badan Kepegawaian dan Pengembangan Sumber Daya Manusia Kabupaten Muaro Jambi dalam melaksanakan aktivitas kerja sehari-hari.

\section{Variabel Disiplin Kerja}

Hasil skor rata-rata jawaban responden mengenai disiplin kerja (X2) sebesar sebesar 3.188 dengan rentang skala $2.730-3.569$, termasuk ke dalam kategori "cukup baik" Dengan demikian, adanya tujuan dan kemampuan, kepemimpinan, balas jasa, keadilan, waskat, ketegasan, serta sanksi, pada akhirnya akan dapat meningkatkan kinerja pegawai pada Badan Kepegawaian dan Pengembangan Sumber Daya Manusia Kabupaten Muaro Jambi

\section{Variabel Kinerja}

Hasil skor rata-rata jawaban responden mengenai kinerja termasuk ke dalam kategori "sangat baik" dengan ratarata variabel kinerja pegawai (Y) sebesar 3.171 dan rentang skala 3.150 - 3.750. Dengan demikian, dilihat dari adanya kualitas kerja, ketepatan waktu, inisiatif, kesanggupan kerja, dan keterampilan berkomunikasi, dapat meningkatkan kinerja pegawai untuk selalu menyumbangkan prestasi kerja mereka, dan pada akhirnya akan meningkatkan kepercayaan para masyarakat terhadap eksistensi dan kinerja yang bertanggung jawab, sesuai dengan tujuan yang diinginkan.

\section{Analisis Inferensial \\ Pengaruh kemampuan kerja (X1) terhadap kinerja pegawai $(Y)$}

Pengaruh langsung kemampuan kerja (X1) terhadap kinerja pegawai (Y) adalah 29,26\% pengaruh tidak langsung sebesar $18,83 \%$ dan pengaruh total sebesar $48,09 \%$. hal ini menunjukan bahwa kemampuan kerja secara langsung berpengaruh positif terhadap kinerja pegawai, sehingga dapat dikatakan semakin tinggi kemampuan kerja yang dimiliki pegawai maka akan semakin tinggi pula kinerja pegawai. 
Hasil pengujian dengan uji parsial (uji t) menggunakan Kinerja Pegawai adalah sebagai berikut : software SPSS 19 Kemampuan kerja (X1) terhadap

Tabel 1

Uji Parsial Kemampuan Kerja (X1) terhadap Kinerja Pegawai (Y)

\begin{tabular}{|c|c|c|c|c|c|c|}
\hline \multirow{2}{*}{\multicolumn{2}{|c|}{ Model }} & \multicolumn{2}{|c|}{ Unstandardized Coefficients } & \multirow{2}{*}{$\begin{array}{c}\text { Standardized } \\
\text { Coefficients } \\
\text { Beta } \\
\end{array}$} & \multirow[b]{2}{*}{$\mathrm{t}$} & \multirow[b]{2}{*}{ Sig. } \\
\hline & & $\mathrm{B}$ & Std. Error & & & \\
\hline \multirow[t]{3}{*}{1} & (Constant) & 173 &, 182 & & 952 & 344 \\
\hline & Kemampuan kerja (X1) & 473 & 094 & .541 & 5,023 & .000 \\
\hline & Disiplin kerja (X2) & ,449 & 123 & ,392 & 3,632 &, 001 \\
\hline
\end{tabular}

Sumber: data diolah

Secara parsial antara variabel kemampuan kerja (X1) dengan variabel kinerja pegawai (Y) menunjukkan bahwa t hitung 5,023 dengan taraf Sig. 0,000. Kriteria keputusan jika Sig. penelitian < 0,05 maka H0 di tolak dan H1 di terima artinya signifikan, tetapi jika Sig. penelitian > 0,05 maka $\mathrm{H} 0$ di terima dan $\mathrm{H} 1$ di tolak yang berarti tidak signifikan. Karena $0,000<0,05$ maka H0 di tolak dan H1 di terima. Hasil ini menunjukkan bahwa secara parsial kemampuan kerja (X1) berpengaruh terhadap kinerja pegawai (Y) pada Badan Kepegawaian dan Pengembangan Sumber Daya Manusia Kabupaten Muaro Jambi dan hipotesis di atas di terima. Hasil penelitian di atas adalah sama dan memperkuat penelitian Anggraeni (2012:72), dimana diungkapkan bahwa kemampuan kerja dan turut berpengaruh terhadap kinerja pegawai di Sekolah Tinggi Seni Indonesia (STSI) Bandung.

\section{Pengaruh disiplin kerja (X2) terhadap kinerja pegawai} (Y)

Pengaruh langsung disiplin kerja (X2) terhadap kinerja pegawai (Y) adalah $15,36 \%$ pengaruh tidak langsung sebesar $18,83 \%$ dan pengaruh total sebesar $34,19 \%$. Artinya kinerja pegawai dipengaruhi oleh disiplin kerja, apabila disiplin pegawai dilakukan pengawasan dan pembinaan yang baik maka akan diperoleh kinerja yang optimal. Secara parsial antara variabel disiplin kerja (X2) dengan variabel kinerja pegawai (Y) aadalah 4.29 menunjukkan bahwa t hitung 3.632 dengan taraf signifikansi 0,001. Kriteria keputusan jika Sig. penelitian $<0,05$ maka H0 di tolak dan H1 di terima artinya signifikan, tetapi jika Sig. penelitian > 0,05 maka $\mathrm{H} 0$ di terima dan $\mathrm{H} 1$ di tolak yang berarti tidak signifikan. Karena $0,001<0,05$ maka H0 di tolak dan H1 di terima. Hasil ini menunjukkan bahwa secara parsial disiplin kerja (X2) berpengaruh terhadap kinerja pegawai (Y) pada Badan Kepegawaian dan Pengembangan Sumber Daya Manusia Kabupaten Muaro Jambi Hasil penelitian di atas adalah sama dan memperkuat penelitian Selviati (2013:13), dimana diungkapkan bahwa disiplin kerja mempengaruhi kinerja para pegawai dalam melaksanakan pekerjaan. Semakin tinggi disiplin kerja, semakin tinggi pula kinerja yang mereka hasilkan.

\section{Pengaruh kemampuan kerja (X1) dan disiplin kerja (X2) terhadap kinerja pegawai $(Y)$}

Berdasarkan tabel model Summary, diperoleh angka $\mathrm{R}$ Square sebesar 0,823 , angka ini menunjukan bahwasannya persentase sumbangan pengaruh variabel independen kemampuan kerja (X1) dan Disiplin kerja (X2) terhadap variabel kinerja pegawai (Y) adalah Angka 82,3\% . Angka tersebut berarti bahwa kemampuan kerja dan disiplin kerja secara bersamasama berpengaruh terhadap kinerja pegawai, sedangkan $17,7 \%$ dipengaruhi atau dijelaskan oleh variabel lain yang tidak dimasukkan dalam model penelitian ini. Selanjutnya, hasil pengujian dengan uji simultan (uji F) menggunakan software SPSS 19, adalah sebagai berikut

Tabel 2

Anova Kemampuan Kerja (X1) - Disiplin Kerja (X2) - Kinerja Pegawai (Y)

\begin{tabular}{|l|l|r|r|r|r|r|}
\hline \multicolumn{2}{|c|}{ Model } & Sum of Squares & Df & Mean Square & F & \multicolumn{1}{c|}{ Sig. } \\
\hline 1 & Regression & 8.969 & $\mathbf{2}$ & 4.485 & 167.413 & $.000^{\mathrm{a}}$ \\
\cline { 2 - 8 } & Residual & 1.929 & 72 & .027 & & \\
\cline { 2 - 7 } & Total & 10.898 & 74 & & & \\
\hline
\end{tabular}

Sumber: data diolah

Secara simultan antara variabel kemampuan kerja (X1) dan variabel disiplin kerja (X2) dengan variabel kinerja pegawai (Y) menunjukkan bahwa $\mathrm{F}$ hitung 167.413 dengan taraf signifikansi 0,000. Kriteria keputusan jika Sig. penelitian <0,05 maka H0 di tolak dan H1 di terima artinya signifikan, tetapi jika Sig. penelitian > 0,05 maka $\mathrm{H} 0$ di terima dan $\mathrm{H} 1$ di tolak yang berarti tidak signifikan. Karena $0,000<0,05$ maka 
H0 di tolak dan H1 di terima. Hasil ini menunjukkan bahwa secara simultan kemampuan kerja (X1) dan disiplin kerja (X2) berpengaruh terhadap kinerja pegawai (Y) pada Badan Kepegawaian dan Pengembangan Sumber Daya Manusia Kabupaten Muaro Jambi. Hasil penelitian di atas memperkuat penelitian Selviati (2013:13), dimana diungkapkan bahwa kemampuan kerja dan disiplin kerja mempengaruhi kinerja pegawai dalam melaksanakan pekerjaan. Semakin tinggi kemampuan kerja dan disiplin kerja, semakin tinggi pula kinerja para pegawai dalam bekerja.

\section{Simpulan}

Hasil penelitian dan pembahasan penelitian sebagaimana dapat ditarik beberapa kesimpulan yang dapat digunakan untuk mengetahui hasil dalam penelitian ini, antara lain sebagai berikut :

1. Kemampuan kerja para pegawai yang ada pada Badan Kepegawaian dan Pengembangan Sumber Daya Manusia Kabupaten Muaro Jambi secara ratarata termasuk ke dalam kategori sangat baik. Selain itu, total capaian responden (TCR) secara rata-rata pada item pernyataan dalam indikator variabel ini memiliki kategori yang tinggi dibandingkan dengan disiplin kerja dan motivasi. Sehingga, dapat dikatakan bahwa kemampuan kerja lebih dominan dalam mempengaruhi kinerja pegawai pada Badan Kepegawaian dan Pengembangan Sumber Daya Manusia Kabupaten Muaro Jambi. Disiplin kerja yang ada pada Badan Kepegawaian dan Pengembangan Sumber Daya Manusia Kabupaten Muaro Jambi secara rata-rata termasuk ke dalam kategori cukup baik. Kinerja pegawai pada Badan Kepegawaian dan Pengembangan Sumber Daya Manusia Kabupaten Muaro Jambi secara rata-rata termasuk ke dalam kategori sangat baik.

2. Pengaruh kemampuan kerja terhadap kinerja pegawai pada Badan Kepegawaian dan Pengembangan Sumber Daya Manusia Kabupaten Muaro Jambi secara parsial positif dan signifikansi. Ini memberikan arti bahwa metode atau cara kerja yang digunakan, metode terbaik atau paling serasi, penggunaan sarana dan prasarana, penggunaan metode atau cara kerja sarana dan prasarana, serta kreativitas, inisiatif, dan sikap kerja yang tepat, maka dapat meningkatkan kinerja pegawai pada Badan Kepegawaian dan Pengembangan Sumber Daya Manusia Kabupaten Muaro Jambi dalam melaksanakan aktivitas kerja sehari-hari.

3. Pengaruh disiplin kerja terhadap kinerja pegawai pada Badan Kepegawaian dan Pengembangan Sumber Daya Manusia Kabupaten Muaro Jambi secara parsial positif dan signifikansi. Ini memberikan arti bahwa dengan adanya tujuan dan kemampuan, kepemimpinan, balas jasa, keadilan, waskat, ketegasan, serta sanksi, pada akhirnya akan dapat meningkatkan kinerja pegawai pada Badan Kepegawaian dan Pengembangan Sumber Daya Manusia Kabupaten Muaro Jambi. Dimana, dengan adanya tingkat disiplin kerja yang tinggi dalam suatu organisasi, maka para pegawai dapat bekerja secara teratur dan terarah, sesuai dengan ketentuan yang ada dalam instansi tersebut.

4. Pengaruh kemampuan kerja dan disiplin kerja secara langsung terhadap kinerja pegawai pada Badan Kepegawaian dan Pengembangan Sumber Daya Manusia Kabupaten Muaro Jambi positif dan signifikansi. Ini memberikan arti bahwa kemampuan kerja dan disiplin kerja secara langsung dapat meningkatkan tanggung jawab dalam melaksanakan pekerjaan sehingga tugas yang diberikan kepada para pegawai dapat berjalan secara optimal dan pada akhirnya tujuan dari instansi tersebut dapat tercapai.

5. secara simultan, terbukti bahwa dari dua variabel independen yang diuji pengaruhnya terhadap kinerja pegawai, ternyata kemampuan kerja mempunyai pengaruh yang lebih dominan terhadap kinerja pegawai pada Badan Kepegawaian dan Pengembangan Sumber Daya Manusia Kabupaten Muaro Jambi. Ini memberikan arti bahwa metode atau cara kerja yang digunakan, metode terbaik atau paling serasi, penggunaan sarana dan prasarana, penggunaan metode atau cara kerja sarana dan prasarana, serta kreativitas, inisiatif, dan sikap kerja yang tepat, maka dapat meningkatkan kinerja pegawai pada Badan Kepegawaian dan Pengembangan Sumber Daya Manusia Kabupaten Muaro Jambi dalam melaksanakan aktivitas kerja sehari-hari.

\section{Daftar Pustaka}

Ali, Hapzi dan Nilakrisma, Nanda (2013). Metodologi Penelitian Petunjuk Praktis Untuk Pemecahan Masalah Bisnis, Penyusunan Skripsi, Tesis dan Disertasi Republik Yogyakarta.

Anggraeni, N. (2012). Pengaruh Kemampuan dan Motivasi Terhadap Kinerja Pegawai Pada Sekolah Tinggi Seni Indonesia (STSI) Bandung. Jurnal Ilmiah Dosen, ISSN : 1412-565X. Hal : 54-74.

Arikunto, Suharsimi. (2007). Prosedur Penelitian Suatu Pendekatan Praktek. Edisi Revisi. Jakarta : PT. Rineka Cipta.

Aroef, M. (2006). Pengukuran Kinerja Kebutuhan Mendasar di Indonesia. Prisma No.11. LP3ES. Jakarta.

Dessler, G. (1999). Human Resources Management. Penerjemah Benyamin Molan. Jakarta : PT. Prehalindo.

Fathoni, A. (2006). Organisasi dan Manajemen Sumber Daya Manusia. Jakarta : PT. Rineka Cipta. 
Fikri, M. (2012). (Tesis). Pengaruh Kepemimpinan dan Motivasi Kerja Terhadap Kinerja Pegawai Pada Dinas Pendapatan Daerah Provinsi Jambi. Magister Manajemen, FE, Universitas Batanghari Kota Jambi, (tidak dipublikasikan).

Gomes, L. (1998). Managing Human Resource". New Jersey : Prentice Hall International, Inc.

Handoko, T.H. (2002). Manajemen Sumber Daya Manusia. Yogyakarta : BPFE UGM.

Hariandja, M.T Effendi. (2002). Manajemen Sumber Daya Manusia. Jakarta : PT. Grasindo.

Harsey, R, Leo J, dan Maynard. (1993). Human Resources Management. New Jersey : Prentice Hall International, Inc.

Harsey, R, Paul, Blanchard, Kenneth H, dan Johnson. (2002). Management of Organizational Behaviour Utilizing Human Resources. New Jersey : Prentice Hall International, Inc.

Hasan, M. Iqbal. (2005). Pokok-pokok Materi Statistik I (statistik deskriptif) ; Edisi Kedua. Jakarta : Bumi Aksara.

Hasibuan, Malayu SP. (2000). Manajemen Sumber Daya Manusia dan Kunci Keberhasilan. Bandung : Armanco.

Ignatius Jeffrey and Marta Herdian Dinata. (2017). The effect of work motivation, work discipline, and competence on employee performance, International Journal Current Advand Reseach, Volume 6; Issue 11; November 2017

(2002). Manajemen Sumber Daya Manusia. Jakarta : Bumi Aksara.

Lubis, F. (2011). (Tesis). Pengaruh Motivasi dan Disiplin Kerja Terhadap Kinerja Pegawai Dinas Pendapatan Daerah Provinsi Jambi. Magister Manajemen, FE, Universitas Batanghari Kota Jambi, (tidak dipublikasikan).

Mangkunegara, A.A. Anwar Prabu.(2000). Manajemen Sumber Daya Manusia. Bandung : PT. Remaja Rosda Karya.

Evaluasi Kinerja SDM. Bandung : PT. Refika Aditama.

Muhidin, S.A \& Maman. (2007). Analisis Korelasi, Regresi, dan Jalur Dalam Penelitian. Bandung : Pustaka Setia.

Ndraha, T. (1999). Pengembangan Sumber Daya Manusia. Jakarta : PT. Rineka Cipta.

Nurul Laras Liestiani, Badia Perizade, Agustina Hanafi, Zunaidah. (2009) The Effect of Work Discipline and Work Environment on the Performance of AL Hudori Cooperative of Palembang Employees, Journal of Economics and Business 04 March 2009

Pangabean, M. (2002). Pengembangan Sumber Daya Manusia. Jakarta : PT. Rineka Cipta.

Ranupandojo, Heidjrahcman, dan Suad H. (2000). Manajemen Personalia. Yogyakarta : BPFE UGM.
Riduwan \& Akdon. (2009). Rumus dan Data dalam Analisis Statistika. Bandung : Alfabeta.

Robbins, S.P. (2001). Perilaku Organisasi. Jakarta : Arcan.

Rubianto, B. (2001). Kepemimpinan Perusahaan Dalam Industri. Jakarta : YKPN.

Sarwani. (2016). The Effect Of Work Discipline And Work Environment On The Performance Of Employees. Jurnal Sinergi, Volume 6, Number2 September 2016

Sastrohadiwiryo, Siswanto. (2002). Manajemen Tenaga Kerja Indonesia : Pendekatan Administratif dan Operasional. Jakarta : Bumi Aksara.

Schermerhorn, J. (2005). Manajemen Strateg. Penerjemah JS Molan. Jakarta : YKPN.

Schuler, J dan Jackson (1996). Manajemen Sumber Daya Manusia, Jilid II. Jakarta : PT. Erlangga.

Sedarmayanti.( 2002). Manajemen Sumber Daya Manusia. Bandung : Mandar Maju.

Selviati, V. (2013). Pengaruh Gaya Kepemimpinan, Motivasi, Disiplin Kerja, dan Kompensasi Terhadap Kinerja Pegawai Bidang Pendapatan, Bidang Anggaran dan Perbendaharaan DPPKAD Kota Tanjungpinang. Jurnal Ilmiah. Hal : 1-15.

Siagian, S. P.(1999). Teori Motivasi dan Aplikasinya. Jakarta : PT. Rineka Cipta.

(2005). Manajemen Sumber Daya Manusia. Bandung : Bumi Aksara.

(2007). Kiat Meningkatkan Produktivitas Kerja. Jakarta : PT. Rineka Cipta.

Sugiyono. (2005). Statistik Untuk Penelitian. Bandung : CV. Alfabeta.

(2012). Metode Penelitian Kuantitatif, Kualitatif Dan Kombinasi (Mixed Methods). Bandung: CV. Alfabeta.

Sulastri, T. (2007). Hubungan Motivasi Berprestasi dan Disiplin Dengan Kinerja Dosen”. Jurnal Optimal, Vol. 1, No. 1, Maret 2007. Hal : 13-21.

Sulistiyani, A.T dan Rosidah. (2003). Manajemen Sumber Daya Manusia. Yogyakarta : Graha Ilmu.

Supardi (2013) Aplikasi Statistika Dalam Penelitian, Konsep Statistika Yang Lebih Komprehensif. cetakan 1 Juni 2013, Change Pulication, Jakarta.

Umar, Husein. (2007). Desain Penelitian MSDM dan Perilaku Karyawan : Paradigma Positivistik dan Berbasis Pemecahan Masalah. Jakarta : PT. Raja Grafindo Persada.

Yuda. (2012) Tesis. Kontribusi Perilaku Kepemimpinan Kepala Sekolah, Motivasi Kerja, dan Disiplin Kerja Terhadap Kinerja Guru Rintisan Sekolah Menengah Atas Bertaraf Internasional (RSMABI) di Kota Denpasar. Universitas Pendidikan Ganesha.

Zuryati. (2005). Metode Penelitian Statistika. Bandung : Remaja Rosda Karya. 